\title{
PHYSICAL ATTRIBUTES AND ORGANIC MATERIAL IN PASTURES OF Brachiaria brizantha AT DEGRADATION LEVELS
}

\author{
Paulo Roberto da ROCHA JUNIOR ${ }^{1}$ (D), Guilherme Kangussú DONAGEMMA ${ }^{2}$ iD, Felipe Vaz ANDRADE ${ }^{3}$ iD, \\ Renato Ribeiro PASSOS ${ }^{2}$ (i), Fabiano de Carvalho BALIERO ${ }^{2}$ iD
}

\footnotetext{
${ }^{1}$ Department of Research and Development, Bioversa, Borborema, São Paulo, Brazil.

${ }^{2}$ Centro Nacional de Pesquisa em Solos, Empresa Brasileira de Pesquisa Agropecuária, Rio de Janeiro, Rio de Janeiro, Brazil.

${ }^{3}$ Departament of Agronomy, CCAE Universidade Federal do Espírito Santo, Alegre, Espírito Santo, Brazil.
}

Corresponding author:

Paulo Roberto da Rocha Junior

Email: rocha.pjunior@gmail.com

How to cite: ROCHA JUNIOR, P.R., et al. Physical attributes and organic material in pastures of Brachiaria brizantha at degradation levels. Bioscience Journal. 2022, 38, e38008. https://doi.org/10.14393/BJ-v38n0a2022-54529

\begin{abstract}
Pastures cover, in Brazil, around 165 million ha, most of them are at some degradation level. Recovering these pastures is essential. The objective of this study was to evaluate the sensibility of soil organic matter (SOM) and its physical attributes in pasture soil at different degradation levels (1 to 4), Capoeiras (1 and 2) and secondary Forest (Control). Samples were collected at four depths (0.00-0.05, 0.05-0.10, 0.10-0.20 and 0.20-0.40 m). We verified higher values for SOM and hydraulic conductivity (Ko) in Forest, especially in the most superficial layer (0.00-0.05). We noted low values for macroporosity in this area. In all areas under Pastures lower values for Ko were observed in the superficial layer (0.00-0.05 $\mathrm{m}$ ) when compared to layers 0.05-0.10 and 0.10-0.20 m, which indicates that the pasture management and cattle trampling negatively affect the physical quality of the pastures. For field capacity and wilting point the average values were observed in Pasture 4 (more degraded), which caused higher values for water availability. According to the principal components analysis, except for SOM at 0.20-0.40 m, all variables studied presented correlation above 0.6. From grouping analysis, we separated 3 groups: Forest; Capoeiras 1 and Capoeira 2 and Pastures 1 to 4 .
\end{abstract}

Keywords: Soil Organic Matter. Soil Physical Attributes. Soil Quality. Soil Water.

\section{Introduction}

Degradation of soil under pastures is a global problem, and in Brazil due to the unsuitable environmental conditions and management, most of these pastures are highly degraded (Zúñiga et al. 2015; Perreira et al. 2018; Sattler et al. 2018; Calegario et al. 2019).

Soil degradation in these areas leads to a decrease of soil organic matter (SOM), resulting in a decrease of soil quality, reducing the ability of these areas to provide environmental services, and reducing the support capacity of these areas (Rocha Junior et al. 2020). Lower production capacity of pasture leads to lower production of protein (meat and milk), which is necessary required in developing countries to meet growing demand for food (Henchion et al. 2017).

In general, pasture degradation is related to several causes, such as low soil fertility and lack of or excessive rainfall, inadequate pasture management practices and failure to establish pasture (Dias Filho 2015). All these causes lead to direct impact on soil properties and, consequently, soil degradation. 
Among the physical properties of the soil, properties related to aggregation, movement and retention of water are considered sensitive (Jat et al. 2018) and can be used to measure the impacts of pasture management (Rocha Junior et al. 2017a). We hypothesized that, even having a relatively stable physical structure, oxidic soils (Oliveira 2007), under different levels of degradation, can have their quality significantly compromised and, from the establishment of precise indicators of the disruption of soil functions, it would be possible to predict the path of degradation and establish strategies for their recovery.

Currently, there are around 183 million hectares of pasture and, most of them, are under some level of degradation, especially in the Atlantic region (Rocha Junior et al. 2017a; MapBiomas 2020). The objective of this study was to evaluate the sensitivity of physical indicators of soil and organic quality in the separation of levels of degraded pastures in Red Argisols of the Atlantic Forest biome. Only in this biome there are about 36 million hectares under pasture (MapBiomas 2020) and the establishment of indicators or levels of degradation for pasture management may guide the planning of livestock in several Brazilian states.

\section{Material and Methods}

\section{Location and characteristics of the study area}

The work was carried out in the municipality of Governador Valadares-MG, Brazil. The study area is located in the Doce River basin, in the Doce River Valley, and the collections were carried out at the Guzerá Duas Meninas farm (Km-401 of BR-116) (Figure 1).

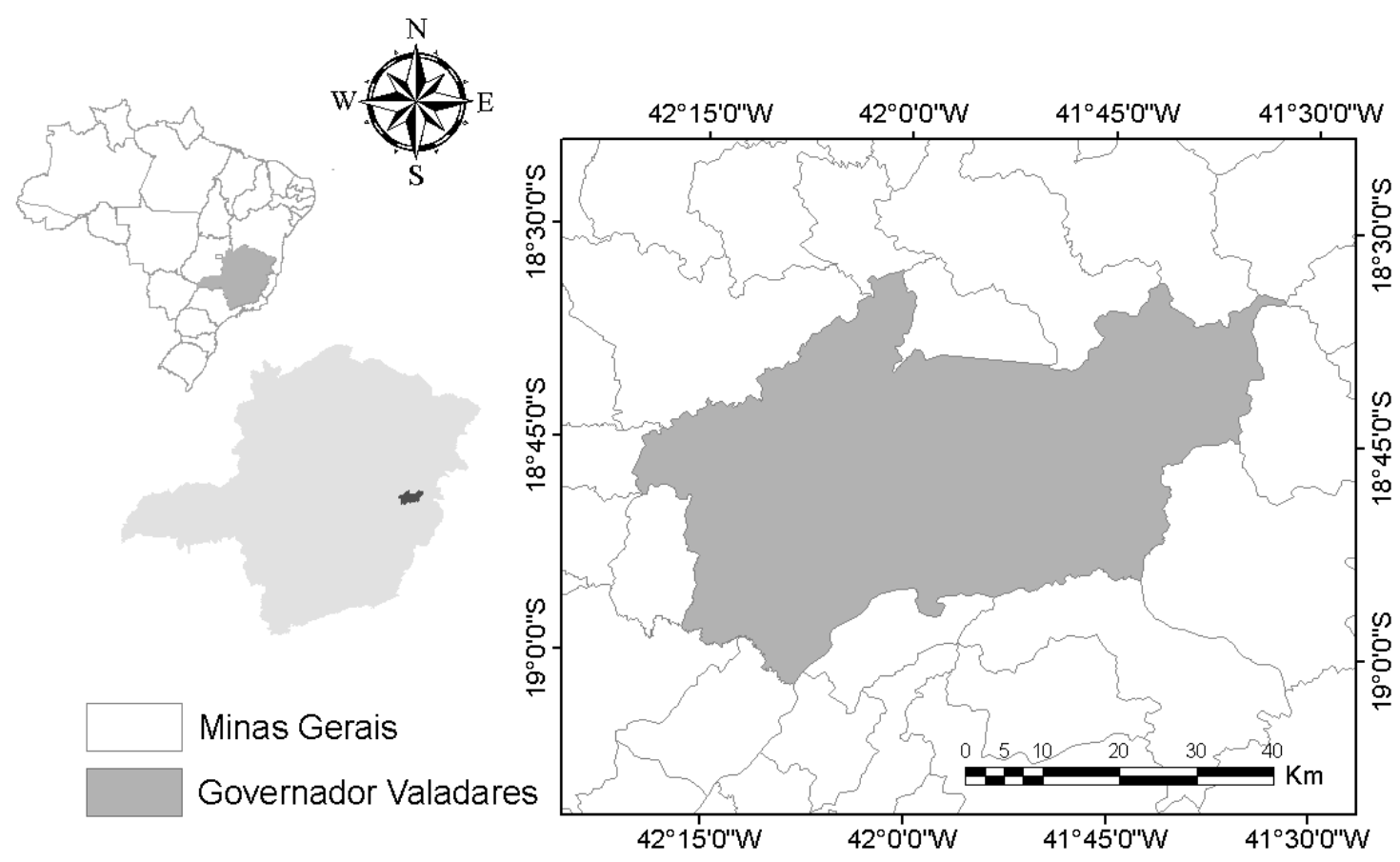

Figure 1. Location of Governador Valadares - MG.

The farm has as activity the beef and dairy cattle being formed with Brachiaria brizantha cv. Marandú having a herd with 180 animals. The management used is with Bos taurus grazing extensively.

The soil under study was classified as argil texture Red Argissol (Embrapa 2018a). This soil is characterized by being a very developed soil and presenting a textural gradient between the horizon A/B. This characteristic makes this class of soil naturally more erodible because a drastic reduction of water infiltration occurs between the horizons. When under inadequate management, erosive processes are high.

\section{Treatments and samplings}

Disturbed and undisturbed samples were collected with volumetric ring at four depths (0.00-0.05, $0.05-0.10,0.10-0.20$ and $0.20-0.40 \mathrm{~m}$ ), with fifteen replicates within each land use, being: four pasture areas in different degradation levels, two capoeiras at different regeneration stages (capoeira 1 and 2) and a secondary forest (about 60 years old), which was used as control in establishing the best level of soil quality 
for the studied variables. The pastures were categorized in the different degradation levels by the proportion of soil cover of the pasture introduced, of the broad and narrow leaf invaders and the percentage of exposed soil, according to Rocha Junior et al. (2017b) and classified according to the soil cover rate (Figure 2) (RochaJunior et al. 2014).

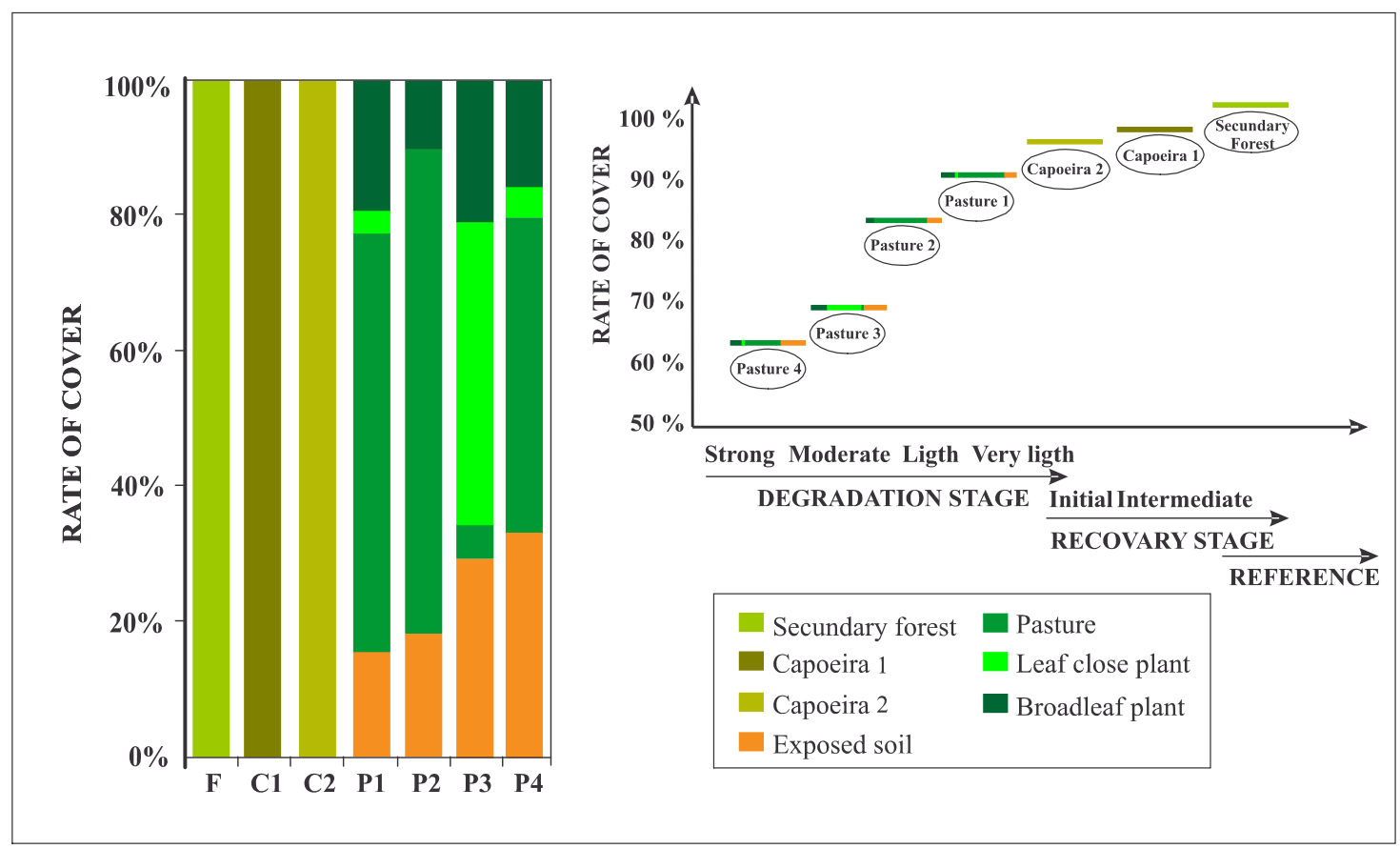

Figure 2. Soil rate of cover for different uses.

The samples were collected in November (rainy season of the year), and all samples were collected in the middle third of a convex-covex pedoform, in a mean slope of $22^{\circ}$.

To evaluate the organic matter content of the soil, the samples were air dried and passed through a $2 \mathrm{~mm}$ sieve to obtain the air-dried fine earth. Afterwards, sub-samples were removed, macerated and all material was passed through a $0.250 \mathrm{~mm}$ sieve to determine the carbon content by dry oxidation in Perkim Elmer 2400 elemental analyzer (CNHS). After obtaining the total organic carbon contents, the values found were multiplied by the factor 1.724 to transform the carbon in soil organic matter (SOM).

In undisturbed samples (volumetric rings) were determined: hydraulic conductivity (Ko) of the soil in a saturated medium according to Ruiz (2004) and the availability of water in the soil was determined by the water retention in a porous plate extractor with the pressures of work: $0.006 \mathrm{Mpa} ; 0.033 \mathrm{Mpa} ; 1.5 \mathrm{Mpa}$ (Embrapa 2018b). Respectively, these pressures are equivalent to macroporosity (Ma), field capacity (FC) and wilting point (WP) of the soil. To determine the available water (WTC) in the soil, the moisture retained in the FC $\left(\mathrm{m}^{3} \mathrm{~m}^{-3}\right)$ - WP $\left(\mathrm{m}^{3} \mathrm{~m}^{-3}\right)$ was subtracted.

\section{Statistical analysis}

The means and mean standard deviations of the studied variables were calculated and the principal components analysis (PCA) was performed, trying to understand which were the most explanatory variables in the different vegetation coverages.

\section{Results}

\section{Mean values of soil organic matter and soil physical attributes}

The mean values of soil organic matter (SOM) between the areas ranged from 1.39 to $4.8 \mathrm{dag} \mathrm{kg}^{-1}$. Numerically, the highest levels were observed in the superficial layer of the soil $(0.00-0.05 \mathrm{~m})$. In general, there was a rapid tendency to decrease SOM contents with a small increase in the soil exposure rate. This effect was more pronounced in the superficial layer (Figure 3). 


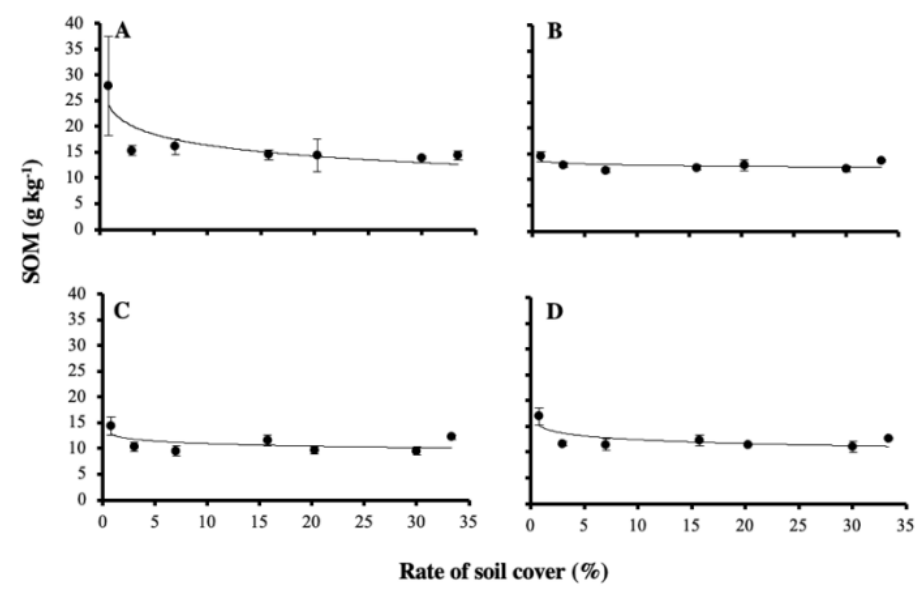

Figure 3. Soil organic matter (SOM) of the soil in a Red Argissol at four depths: A - 0.00-0.05; B-0.05-0.10; $C-0.10-0.20$; and $D-0.20-0.40 \mathrm{~m}$, under different soil exposure rates.

Except for the area with $0 \%$ soil exposure (forest), there was a tendency to stabilize the levels of SOM after $2 \%$ soil exposure (Figure 3 ).

The macroporosity data ( $\mathrm{Ma}$ ) are shown in Figure 4. The variation of $\mathrm{Ma}$ between the different exposure rates studied was 0.08 to $0.38 \mathrm{~m}^{3} \mathrm{~m}^{-3}$, and, in general, the highest averages were observed in the 0.05-0.10 m layer. The Ma tended to decrease after the elevation of the soil exposure rate, except for the 0.05-0.10 m layer, where the opposite effect was verified. The increase in soil exposure led to an increase in $\mathrm{Ma}$, with the porosity increase rate being $13 \%$, when evaluated from $0 \%$ to $35 \%$ (Figure 4).

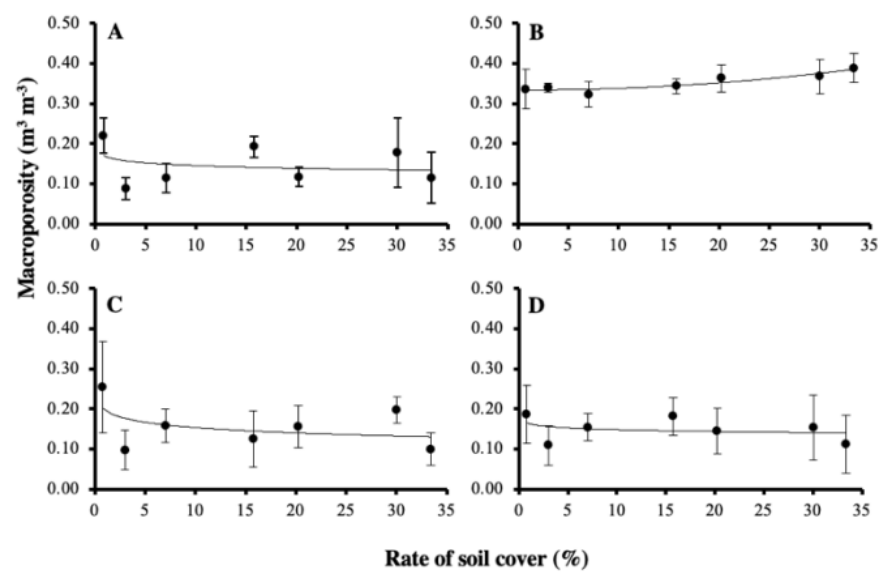

Figure 4. Macroporosity of soil (Ma) in a Red Argisol at four depths: $A-0.00-0.05 ; B-0.05-0.10 ; C-0.10-$ 0.20 ; and $D-0.20-0.40 \mathrm{~m}$, under different soil exposure rates.

The hydraulic conductivity data (Ko) are shown in Figure 5. For Ko, the mean amplitude of variation was 1.61 to $112.87 \mathrm{~mm} \mathrm{~h}^{-1}$. As in other soil attributes, soil exposure had a strong influence on Ko, since, after exposure, Ko decreased to the point of the order of $97.61 \%$ in the $0.00-0.05 \mathrm{~m}$ layer, $72.73 \%$ in the $0.05-0.10$ $\mathrm{m}$ layer, $75.87 \%$ in the $0.10-0.20$ layer and $98.20 \%$ in the $0.20-0.40 \mathrm{~m}$ layer.

With the exception of the value found at the $0.20-0.40 \mathrm{~m}$ layer at the $0 \%$ exposure rate, the highest Ko values were observed at the 0.05-0.10 m layer (Figure 5).

Regarding the field capacity (FC) and wilting point (WP), the values varied between 0.35 and $0.24 \mathrm{~m}^{3}$ $\mathrm{m}^{-3}$ for FC and 0.24 to $0.16 \mathrm{~m}^{3} \mathrm{~m}^{-3}$ for WP (Figure 6). In all depths, in general, a tendency to higher values of FC between soil exposure rates with $0-7 \%$ of exposed soil and $30-33 \%$ of exposed soil is observed. At these same soil exposure ranges a trend was observed for lower WP values (Figure 6).

For water retention (WTF), the values varied between 0.10 a $0.04 \mathrm{~m}^{3} \mathrm{~m}^{-3}$. Among the soil exposure rates 8 and 29\%, the lowest values of water retention were observed (Figure 6). 


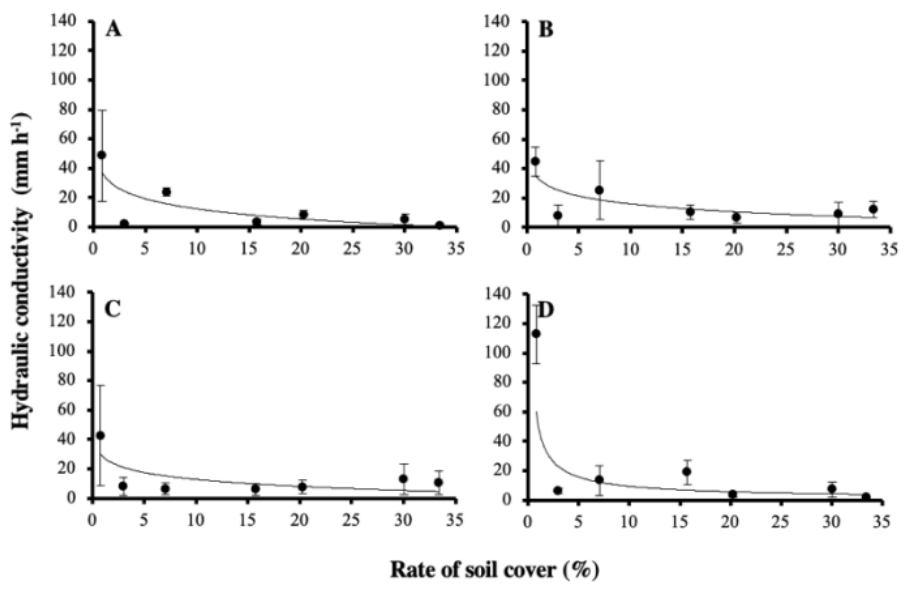

Figure 5. Soil hydraulic conductivity (Ko) in a Red Argisol at four depths: A-0.00-0.05; B-0.05-0.10; C0.10-0.20; and $D-0.20-0.40 \mathrm{~m}$, under different soil exposure rates.

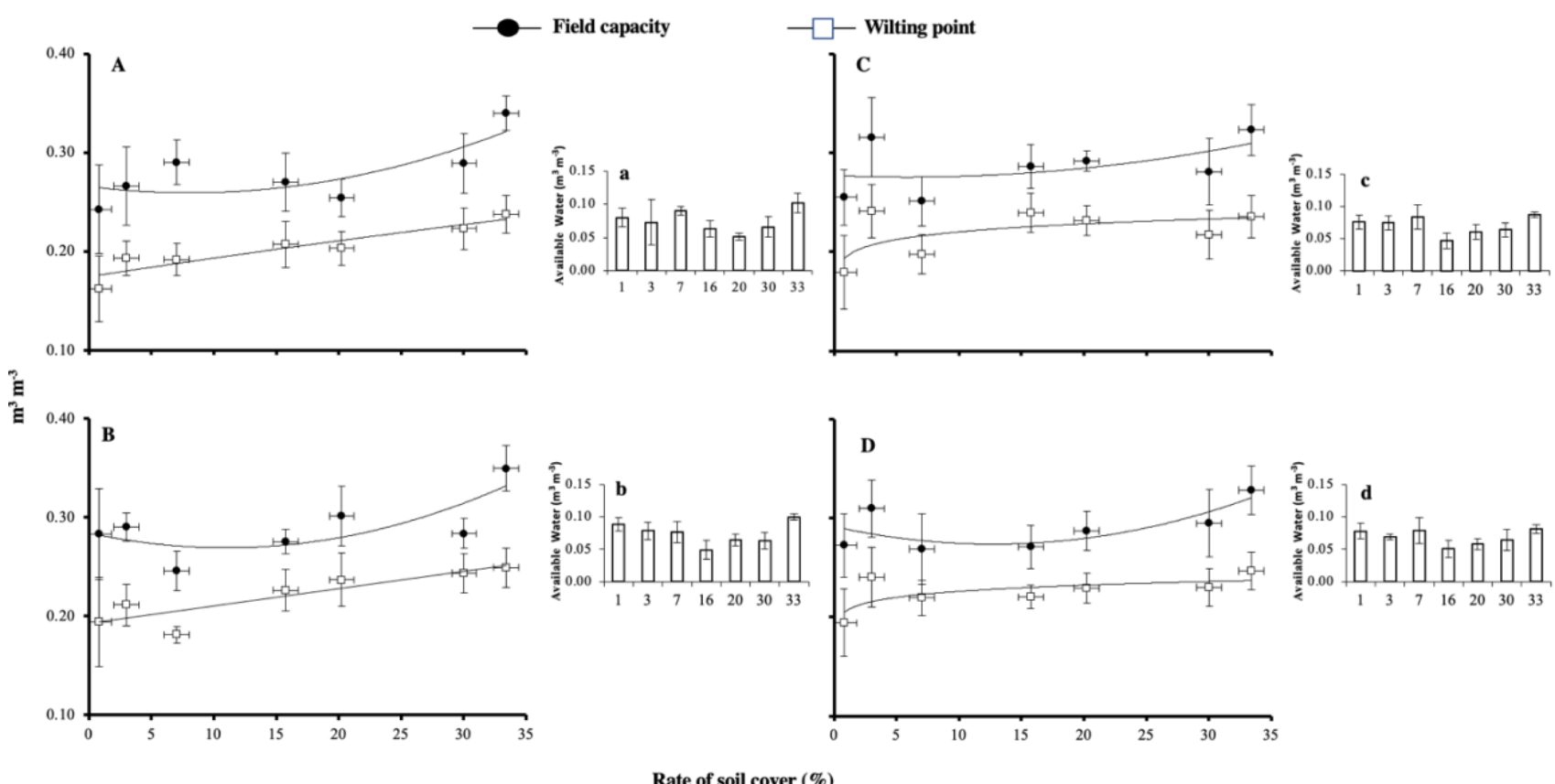

Figure 6. Capital letters field capacity (FC) and wilting point (WP) in a Red Argissol at four depths: $A-0.00$ -

0.05; $B-0.05-0.10 ; C-0.10-0.20$; and $D-0.20-0.40 \mathrm{~m}$, under different soil exposure rates. Lowercase letters available water (AW) in a Red Argissol at four depths: $a-0.00-0.05 ; b-0.05-0.10 ; c-0.10-0.20$, and $d-0.20-0.40$, under different soil exposure rates.

\section{Multivariate analysis of principal components and grouping}

In the multivariate analysis for soil physical attributes and for SOM, components 1 and 2 explained up to $80.28 \%$ of the discriminant functions generated. With the exception of SOM in the depth $0.20-0.40 \mathrm{~m}$, all other soil attributes studied with their respective depths showed a correlation with the principal components with values above 0.6 (Table 1). This result shows that the attributes and depths chosen largely explain the variability of the different areas studied. 
Table 1. Correlation (\%) between each principal component and soil attributes for the layers $0.00-0.05,0.05-$ $0.10,0.10-0.20$ and $0.20-0.40 \mathrm{~m}$ of the dystrophic Red Argisol under different levels of degraded pastures, capoeiras and forest.

\begin{tabular}{|c|c|c|c|c|c|c|c|c|}
\hline \multirow{2}{*}{ Attributes } & $1 \backslash \mathrm{PC} 1$ & PC2 & PC1 & PC2 & PC1 & PC2 & PC1 & PC2 \\
\hline & \multicolumn{2}{|c|}{$0.00-0.05 \mathrm{~m}$} & \multicolumn{2}{|c|}{$0.05-0.10 \mathrm{~m}$} & \multicolumn{2}{|c|}{$0.10-0.20 \mathrm{~m}$} & \multicolumn{2}{|c|}{$0.20-0.40 \mathrm{~m}$} \\
\hline${ }^{21} \mathrm{SOM}$ & -0.91 & 0.359 & 0.274 & 0.884 & 0.587 & 0.612 & -0.584 & 0.577 \\
\hline${ }^{3} \mathrm{Ma}$ & 0.647 & -0.014 & 0.974 & 0.025 & 0.917 & -0.283 & -0.954 & -0.167 \\
\hline${ }^{4} \bigvee_{\mathrm{Ko}}$ & -0.901 & 0.373 & -0.551 & 0.765 & 0.904 & 0.29 & 0.851 & 0.517 \\
\hline$\left.{ }^{5}\right|_{F C}$ & 0.788 & 0.586 & 0.936 & 0.317 & -0.772 & 0.54 & 0.973 & -0.039 \\
\hline${ }^{61} \mathrm{WP}$ & 0.919 & 0.031 & 0.922 & -0.328 & -0.952 & 0.089 & -0.812 & 0.499 \\
\hline${ }^{7}$ WTC & 0.168 & 0.975 & 0.246 & 0.854 & 0.213 & 0.654 & 0.187 & 0.961 \\
\hline${ }^{8 \backslash} \mathrm{CV}(\%)$ & \multicolumn{2}{|c|}{85.22} & \multicolumn{2}{|c|}{90.31} & \multicolumn{2}{|c|}{80.28} & \multicolumn{2}{|c|}{90.29} \\
\hline
\end{tabular}

${ }^{1 \backslash P C 1}$ - first principal component, PC2 - second principal component; ${ }^{2 \backslash S O M}$ - Soil organic matter; ${ }^{3 \backslash} \mathrm{Ma}$ - Macroporosity; ${ }^{4 \backslash K o}$ Hydraulic Conductivity in Saturated Medium; ${ }^{5} \mathrm{FC}$ - Field capacity; ${ }^{6}$ Wilting point; ${ }^{7 \backslash W T C}$ - Available water; ${ }^{8 \backslash} \mathrm{CV}$ - Cumulative Variance.

\section{Discussion}

With the decrease of soil organic matter content (SOM) with increased soil exposure we concluded that the replacement of vegetation cover for implantation of pasture and the inadequate pasture management reduce the soil quality (Rocha Junior et al. 2018a). It was clear that 6 and 8 years are not yet the time required to recover soil organic matter in areas that were previously degraded pastures, especially when dealing with deeper layers. Even recomposition with capoeiras. Possibly due to the magnitude of the impact previously suffered by the high trampling, the exposure of the soil and the erosive processes, the strategy of natural recomposition in the capoeiras may take a longer time than expected. Other alternatives to recover the soil may be viable, such as the adoption of exotic grasses with high growth potential in impacted environments, but with great potential to contribute to the soil with organic matter (Silva et al. 2013).

The greatest difference in SOM, observed in the 0.00-0.05 $\mathrm{m}$ layer, between soil exposure rates is possibly related to erosive processes occurring in pastures with higher soil exposure that may have promoted greater loss of SOM (Rocha Junior et al. 2017a; Rocha Junior et al. 2020) compared to forest. Although forest areas usually show higher root growth (Rocha Junior et al. 2017b), this characteristic did not influence the levels of SOM in depth.

The subtle difference observed for the macroporosity ( $\mathrm{Ma}$ ) in the secondary forest in relation to the degraded pastures in the layers $0.00-0.05,0.10-0.20$ and $0.20-0.40 \mathrm{~m}$, as well as the smaller values of forest porosity in the layer $0.05-0.10 \mathrm{~m}$, is possibly related to a more significant relationship between macro and micropores (data not shown). In addition, frequent fires in these pasture areas may have influenced to this result, providing increased porosity with increased carbon input to the soil in the form of coal.

The increase of the coal content in the soil related to the increase of soil porosity has been pointed out in the literature, especially in studies with biochar (Jien and Wang 2013). These authors have demonstrated a series of benefits with the increase of the contribution of $C$ in the form of coal to the soil, such as the reduction of the soil density, the greater infiltration of water in the soil and the reduction of the erosive processes. Although there are benefits with the contribution of coal to the soil, due to the higher soil exposure in the areas of degraded pastures, this effect can be undone owning to the direct impact of rainfall with soil disintegration and surface sealing, reducing the infiltration rate of water in the soil and increasing the surface runoff (Rocha Junior et al. 2018b; Bombino et al. 2019). In addition, it is emphasized that the coal brought to the soil by vegetation burning raises the levels of SOM, because the coal is in a very stable form. Coal stays in the soil longer and is not oxidized in form of $\mathrm{C}-\mathrm{CO}_{2}$ (Blanco-Canqui et al. 2020), a fact not observed in the present study.

Although a direct relation of hydraulic conductivity (Ko) with macroporosity (Ma) (Centeno et al. 2020) is pointed out in the literature, this aspect was not verified in the present study. The larger Ko in the forest area with lower Ma values is indicative of greater pore connectivity (possibly biospores) of the superficial layer with the deeper layers in this area. 
The lower value of $\mathrm{Ma}$ in forest area is related to the better relation between macro and micropores. In addition, in Argisol, from the B horizon, micropores naturally predominates on macropores, typical of the densification that this horizon presents.

In the other areas, Capoeiras ( 1 and 2 ) and Pastures ( 1 to 4 ), the results verified were contrary to the forest, where higher $\mathrm{Ma}$ and lower Ko were observed. Possibly the pores found in these areas, with higher soil exposure, are planar, which means, parallel to the surface, causing lower hydraulic conductivity and higher surface runoff, indicating that higher total porosity does not always means higher structural quality. This fact has been proven in a study developed by Oliveira (2000), which demonstrated a high macroporosity, based on micromorphological analysis in exposed soil areas, but with low hydraulic conductivity, justifying the arrangement of planar pores.

In the present study it is clear that substitution of forest for pasture at any intensity reduces hydraulic conductivity in the soil, and the large discrepancy in the $0.20-0.40 \mathrm{~m}$ layer reinforces the potential that the root systems of a forest have in promoting deep structuring and increasing water recharge, reinforcing the importance of adopting rotational systems or systems integrated with pasture. Teague et al. (2011) demonstrated that light continuous grazing systems were the key to reduce runoff and, consequently, to increase soil water infiltration when compared to heavy continuous grazing area. Aguiar et al. (2010) demonstrated a direct relationship of silvopastoral systems with hydraulic conductivity and reduction of soil and water losses compared to pastures under conventional management.

In the evaluation of FC, WP and WTC, it was verified that these attributes of the soil had no direct relation with the soil exposure rate, but with the intensity of the soil use. It was observed that the areas with lower intensity of use as forest area, capoeiras ( 1 and 2 ) and Pasture 4 were the areas that presented higher values of water retention. In Pasture 4, due lower availability of grass in this area and higher density of invasive plants, the reduction of trampling has been observed, which, consequently, increased porosity and field capacity which may have increased the availability of water in the soil. In addition, a higher coal content in the soil was verified in this area (data not shown). As coal has a higher specific surface, higher content of coal in soil implies higher water retention capacity (Tanure et al. 2019).

On the other hand, pastures 1, 2 and 3, because they have a higher availability of grass, may be suffering with higher intensity of trampling, reducing the capacity of retention of water in the soil.

The results found for the water in the soil show that the areas of Forest and Capoeiras ( 1 and 2) present better relation between pores and water retention, but Pastures 1, 2 and 3, even with good soil cover compared to Pasture 4, need to have the soil management adjusted for presenting smaller rates of water retention, which may cause water loss by surface runoff and increase erosion processes and nutrient losses (Teague et al. 2011).

\section{Conclusions}

The structural quality of the soil varies with the degradation levels of pastures, observing better quality under Forest due to higher contents of SOM in all the depths studied, and, consequently, higher Ko.

The water retention was influenced by the degradation levels. Pasture 4 presented higher retention of water, due to high carbon content in the soil, with contribution of higher presence of coal in this pasture. The higher level of degradation, the higher water retention. It also means higher risk of erosion, on the other hand.

The Ko in the superficial layers varies inversely proportional with the degradation level, indicating that the effect of animal trampling is causing compaction, even in the areas with greater vegetation cover; thus, causing a greater risk of erosion.

The attributes and depths chosen largely to explain the variability of the different areas studied. It is possible to separate three groups according to the attributes studied: Forest at depths 0.00-0.05, 0.05-0.10 and 0.10-20 m; Pastures (1-4) and Capoeiras ( 1 and 2 ) at depths 0.00-0.05, 0.05-0.10; 0.10-20 and 0.20-0.40 $\mathrm{m}$; and Forest at depth $0.20-0.40 \mathrm{~m}$. It was not possible to separate the pastures' degradation levels with the indicators used, but rather the reference (forest), areas in recovery (Capoeiras 1 and 2) and pastures with some degradation level. 
Authors' Contributions: ROCHA JUNIOR, P.R.: conception and design, acquisition of data, analysis and interpretation of data, drafting the article; DONAGEMMA, G.K.: acquisition of data, analysis and interpretation of data, drafting the article; ANDRADE, F.V.: conception and design, analysis and interpretation of data, drafting the article; PASSOS, R.R.: analysis and interpretation of data, drafting the article; BALIERO, F.C.: analysis and interpretation of data, drafting the article. All authors have read and approved the final version of the manuscript.

Conflicts of Interest: The authors declare no conflicts of interest.

Ethics Approval: Not applicable.

Acknowledgments: The authors would like to thank the funding for the realization of this study provided by the Brazilian agencies CAPES (Coordenação de Aperfeiçoamento de Pessoal de Nível Superior - Brasil), Finance Code 001, and CNPq (Conselho Nacional de Desenvolvimento Científico e Tecnológico - Brasil). The authors are also grateful to Zezé for contribution with field collections.

\section{References}

AGUIAR, M.I., et al. Sediment, nutrient and water losses by water erosion under agroforestry systems in the semi-arid region in northeastern Brazil. Agroforestry Systems. 2010, 79(3), 277-289. https://doi.org/10.1007/s10457-010-9310-2

BOMBINO, G., DENISI, P., GOMEZ, J.A. and ZEMA, D.A. Water Infiltration and Surface Runoff in Steep Clayey Soils of Olive Groves under Different Management Practices. Water. 2019, 11(240), 1-13. https://doi.org/10.3390/w11020240

BLANCO-CANQUI, H., et al. Soil carbon increased by twice the amount of biochar carbon applied after 6 years: Field evidence of negative priming. GCB Bioenergy. 2020, 12, 240-251. https://doi.org/10.1111/gcbb.12665

CALEGARIO, A.T., et al. Mapping and characterization of intensity in land use by pasture using remote sensing. Revista Brasileira de Engenharia Agrícola e Ambiental. 2019, 23(5), 352-358. https://doi.org/10.1590/1807-1929/agriambi.v23n5p352-358

CENTENO, L.N., et al. Dominant Control of Macroporosity on Saturated Soil Hydraulic Conductivity at Multiple Scales and Locations Revealed by Wavelet Analyses. Journal of Soil Science and Plant Nutrition. 2020, 20, 1686-1702. https://doi.org/10.1007/s42729-020-00239-5

DIAS FILHO, M.B. Estratégias de recuperação de pastagens degradadas na Amazônia brasileira. Embrapa Amazônia Oriental-Documentos (INFOTECA-E), 2015.

EMPRESA BRASILEIRA DE PESQUISA AGROPECUÁRIA - EMBRAPA (a). Centro Nacional de Pesquisa de Solos. Sistema brasileiro de classificação de solos. 5th ed. Rio de Janeiro, 2018.

EMPRESA BRASILEIRA DE PESQUISA AGROPECUÁRIA - EMBRAPA (b). Centro Nacional de Pesquisa de Solos. Manual de métodos de análise de solos. 3rd ed. Rio de Janeiro, 2017.

HENCHIO, M., et al. Future Protein Supply and Demand: Strategies and Factors Influencing a Sustainable Equilibrium. Foods. 2017, 6(7), 53. https://doi.org/10.3390/foods6070053

JAT, M.L., et al. 2018. Soil Processes and Wheat Cropping Under Emerging Climate Change Scenarios in South Asia. In: SPARKS, D. L. (ed.). Advances in Agronomy. New York: Academic Press, pp. 111-171.

JIEN, S.H. and WANG, S.S. Effects of biochar on soil properties and erosion potential in a highly weathered soil. Catena. 2013, 110, 225-233. https://doi.org/10.1016/j.catena.2013.06.021

MAPBIOMAS - Plataforma MAPBIOMAS v.4.1. Available: https://plataforma.mapbiomas.org/map\#coverage

OLIVEIRA, J.B. Pedologia aplicada. 4 ed. Piracicaba: FEALQ, 2007.

OLIVEIRA, M.L. Camadas superficiais adensadas em resposta a radiação solar, temperatura e umidade do solo. Viçosa: Universidade Federal de Viçosa, 2000. Tese de doutorado.

PERREIRA, L.F., FERREIRA, C.F.C. and GUIMARAES, R.M.F. Manejo, qualidade e dinâmica da degradação de pastagens na Mata Atlântica de Minas Gerais - Brasil. Nativa. 2018, 6, 370-379. http://dx.doi.org/10.31413/nativa.v6i4.5542

ROCHA JUNIOR, P.R., et al. Soil quality indicators to evaluate environmental services at different landscape positions and land uses in the Atlantic Forest biome. Environmental and Sustainability Indicators. 2020, 7, p100047. https://doi.org/10.1016/j.indic.2020.100047

ROCHA JUNIOR, P.R., et al. Can short-term pasture management increase $\mathrm{C}$ balance in the Atlantic Rainforest? Environmental Monitoring and Assessment. 2018a, 190, 190-343. https://doi.org/10.1007/s10661-018-6718-z

ROCHA JUNIOR, P.R., et al. Runoff sediment and P losses from various soil management practices: modelling in hilly slopes. Journal of Soil Science and Plant Nutrition. 2018b, 1, 113-128. http://dx.doi.org/10.4067/S0718-95162018005000502

ROCHA JUNIOR, P.R., et al. Soil, water, and nutrient losses from management alternatives for degraded pasture in Brazilian Atlantic Rainforest biome. Science of the Total Environment. 2017a, 583, 53-63. https://doi.org/10.1016/i.scitotenv.2016.12.187

ROCHA JUNIOR, P.R., et al. Field-based quality indicators in degraded pasture of the Atlantic forest biome. Australian Journal of Crop Science. 2017b, 11, 652-661. https://doi.org/10.21475/ajcs.17.11.06.p326

ROCHA JUNIOR, P.R., et al. Can Soil Organic Carbon Pools Indicate the Degradation Levels of Pastures in the Atlantic Forest Biome? Journal of Agricultural Science. 2014, 6(1), 84-95. http://dx.doi.org/10.5539/jas.v6n1p84 
RUIZ, H.A. Material didático da disciplina SOL 640 - Física do Solo. Métodos de análises físicas do solo. Viçosa: Universidade Federal de Viçosa, 2004.

SATTLER, D., et al., 2018. Pasture degradation in Southeast Brazil - Status, Drivers and Options for sustainable land use under climate change. In: LEAL FILHO, W. and ESTEVES FREITAS, L. (Eds.). Climate Change Adaption in Latin America-Managing Vulnerability, Fostering Resilience. Climate Change Management, New York: Springer, pp. 3-17.

SILVA, L.C.R., et al. Unprecedented carbon accumulation in mined soils: the synergistic effect of resource input and plant species invasion. Ecological Applications. 2013, 23, 1345-1356. https://doi.org/10.1890/12-1957.1

TANURE, M.M.C., et al. Soil Water Retention, Physiological Characteristics, and Growth of Maize Plants in Response to Biochar Application to Soil. Soil and Tillage Research. 2019, 192, 164-173. https://doi.org/10.1016/j.still.2019.05.007

TEAGUE, W.R., et al. Grazing management impacts on vegetation, soil biota and soil chemical, physical and hydrological properties in tall grass prairie. Agriculture, Ecosystems and Environment. 2011, 141, 310-322. https://doi.org/10.1016/i.agee.2011.03.009

ZÚÑIGA, F., et al. Temporal dynamics of the physical quality of an Andisol under a grazing system subjected to different pasture improvement strategies. Soil and Tillage Research. 2015, 145, 233-241. https://doi.org/10.1016/j.still.2014.09.014

Received: 7 May 2020 | Accepted: 12 October 2021 | Published: 16 February 2022

This is an Open Access article distributed under the terms of the Creative Commons Attribution License, which permits unrestricted use, distribution, and reproduction in any medium, provided the original work is properly cited. 